Dados - Revista de Ciências Sociais

ISSN: 0011-5258

dados@iesp.uerj.br

Universidade do Estado do Rio de Janeiro

Brasil

Neto Amorim, Octavio

Presidential cabinets, electoral cycles, and coalition discipline in Brazil

Dados - Revista de Ciências Sociais, vol. 43, núm. 3, 2000, p. 0

Universidade do Estado do Rio de Janeiro

Rio de Janeiro, Brasil

Disponível em: http://www.redalyc.org/articulo.oa?id=21843303

- Como citar este artigo

- Número completo

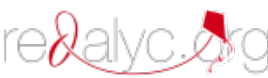

Mais artigos

- Home da revista no Redalyc

Sistema de Informação Científica

Rede de Revistas Científicas da América Latina, Caribe , Espanha e Portugal

Projeto acadêmico sem fins lucrativos desenvolvido no âmbito da iniciativa Acesso Aberto 


\title{
DADOS \\ Gabinetes Presidenciais, Ciclos Eleitorais e Disciplina Legislativa no Brasil ${ }^{1}$
}

Octavio Amorim Neto

\begin{abstract}
INTRODUÇÃO
Estudos recentes sobre o presidencialismo latino-americano (Amorim Neto, 1998; Deheza, 1998; Thibaut, 1998) mostram que os governos de coalizão são mais freqüentes nessa região do que supõem os teóricos desse sistema de governo (J ones, 1995; Lijphart, 1992; Linz, 1994). Embora esses resultados mostrem que as democracias presidencialistas do Terceiro Mundo são capazes de criar mecanismos extraconstitucionais para enfrentar a suscetibilidade a crises que caracteriza os presidentes minoritários, resta verificar se os gabinetes presidenciais $\underline{1}$ multipartidários podem funcionar como as coalizões de tipo parlamentarista que, em geral, exibem um alto grau de disciplina no plenário do Parlamento e atuam em sintonia com o Executivo na proposição de projetos legislativos.
\end{abstract}

O Brasil é um bom ponto de partida para o exame dessa questão. Existe um debate na literatura comparativa sobre o presidencialismo a respeito de que padrão de formação de governos predomina no Brasil. De um lado, Abranches (1988), Deheza (1997:192-230) e Meneguello (1998) sustentam que todos os presidentes brasileiros formam governos de coalizão. De outro, Amorim Neto (1994; 1995) e Thibaut (1996:282-321) advertem contra uma aplicação pouco rigorosa do conceito de governo de coalizão aos sistemas presidencialistas, alegando que outros tipos de ministérios também têm sido formados neste país. Enquanto Abranches, Deheza e Meneguello simplesmente contam o número de partidos recrutados para o Gabinete para caracterizar-lhe a condição de coalizão, Amorim Neto e Thibaut também levam em conta as estratégias de cooptação (opostas às de coalizão) que os presidentes usam para negociar com os partidos políticos e os atores sociais, bem como os critérios empregados no recrutamento de cada ministro. No entanto, esses cinco autores somente oferecem exemplos ilustrativos a respeito de como o processo legislativo está associado com o tipo de Gabinete escolhido pelo chefe do Executivo. A natureza de um Gabinete presidencial não depende apenas de se é constituído por um ou mais partidos e de ter ou não o controle de uma maioria de cadeiras no Legislativo. Os gabinetes presidenciais também variam de acordo com o modo como os partidos estão neles representados. Estudiosos da política de coalizão na Europa têm proporcionado fartas evidências de que os partidos que compõem governos de coalizão normalmente recebem recompensas ministeriais proporcionais ao seu peso no Legislativo (Browne e Franklin, 1973; Budge e Keman, 1990:88-131; Laver e Schofield, 1990: 164-194; Schofield e Laver, 1985). Entretanto, como nos sistemas presidencialistas a Constituição dá liberdade aos presidentes para formar os gabinetes que quiserem, eles podem nomear um Ministério multipartidário que não necessariamente recompense os partidos de acordo com o princípio de proporcionalidade. Quais são as conseqüências dessa estratégia de formação de coalizões? Será ela responsável por menores taxas de apoio parlamentar ao presidente por parte dos partidos presentes no Gabinete? Uma distribuição eqüitativa dos postos ministeriais entre os partidos ajudaria a fortalecer o apoio ao presidente?

Enquanto essas questões sobre a influência dos gabinetes no comportamento legislativo não forem adequadamente respondidas, qualquer tentativa de dizer que os ministérios multipartidários, no Brasil ou em qualquer outro sistema presidencialista, funcionam de modo equivalente aos acordos de coalizão de tipo parlamentarista despertará justificado ceticismo. Afinal de contas, como bem disse Sartori (1997:161), "[...] os problemas do presidencialismo não se encontram na arena do Executivo, mas na do Legislativo".

Este artigo procura analisar o impacto de como a distribuição de postos ministeriais entre os partidos influi no comportamento legislativo destes últimos no Brasil, no período 1989-1998, usando dados relativos a votações nominais. Os efeitos de outras variáveis relevantes no comportamento legislativo dos partidos, tais como o decurso do mandato presidencial e a diversidade ideológica do Ministério, também serão examinados.

O período histórico mencionado fornece um cenário adequado à verificação do impacto dos gabinetes no comportamento legislativo em um só país, pois existem importantes variações tanto nesse comportamento quanto na composição dos gabinetes entre diversos períodos presidenciais e durante um mesmo governo. Sabendo-se que os presidentes costumam formar diferentes ministérios no decorrer dos seus mandatos, tenho a possibilidade de examinar como as mudanças ministeriais afetam o comportamento legislativo, mantendo constantes muitos fatores intangíveis que influem sobre o comportamento de presidentes e legisladores. Além disso, tendo em vista que as taxas de disciplina partidária no Brasil variam entre as legendas e ao longo do tempo, é possível testar o impacto da composição do Gabinete sobre estas taxas. 


\section{DADOS}

Um fator de grande importância nas relações entre Executivo e Legislativo na América Latina é a habilidade dos presidentes para forjar maiorias que respaldem suas ações. Entretanto, o comportamento das coalizões nos regimes presidencialistas é um aspecto pouco estudado da política latino-americana. Este artigo é uma tentativa de fazer avançar nosso conhecimento a respeito do comportamento das coalizões nos sistemas presidencialistas latino-americanos, mediante a realização de um estudo de caso. O texto também oferece uma extensão da bibliografia sobre partidos brasileiros que destaca a fraqueza da disciplina partidária (Amorim Neto e Santos, no prelo; Figueiredo e Limongi, 1995²; Mainwaring e Pérez Liñán, 1998) e o uso pelos presidentes de recursos orçamentários e do seu poder de agenda para reunir apoio legislativo (Amorim Neto e Santos, no prelo; Limongi e Figueiredo, 1998; Santos, 1997).

O artigo está estruturado da seguinte forma: na próxima seção, proponho um método quantitativo para medir o grau de coalescência dos gabinetes presidenciais com base na distribuição de pastas ministeriais aos partidos políticos. Defino Gabinete de coalizão como aquele que inclui pelo menos dois partidos e exibe um alto grau de proporcionalidade entre a cota ministerial dos partidos e seu peso parlamentar. A aplicação desse indicador para o caso brasileiro revela uma considerável variação no grau de coalescência dos gabinetes. Na terceira seção, faço uma rápida descrição da estrutura institucional brasileira no período 1985-1999 e mostro como essa estrutura se relaciona com a política de formação de gabinetes. A quarta seção analisa séries temporais para examinar o impacto do grau de proporcionalidade entre as cotas ministeriais dos partidos e seus pesos no Legislativo, e de mais duas variáveis que dizem respeito ao perfil ideológico dos ministérios e o decurso do mandato presidencial, sobre a disciplina legislativa dos partidos representados no Gabinete, mediante o estudo das votações nominais realizadas no período de 1989 a 1998. As análises mostram que a disciplina legislativa varia principalmente com o grau de coalescência do Gabinete e com o decorrer do mandato presidencial. Na quinta seção, apresento testes estatísticos para determinar o nível de apoio de partidos específicos ao Executivo, mostrando que o apoio dos maiores partidos brasileiros ao presidente da República depende da taxa de recompensa ministerial do partido (ministerial payoff ratio), da passagem do tempo ou decurso do mandato presidencial e, no caso de alguns partidos, de sua distância ideológica em relação às preferências políticas do chefe do Executivo. A sexta seção apresenta as conclusões.

\section{O GRAU DE COALESCÊNCIA DOS GABINETES PRESIDENCIAIS}

O objetivo desta seção é propor um indicador baseado na distribuição partidária das pastas ministeriais, o qual nos permitirá ao mesmo tempo medir a coalescência dos gabinetes presidenciais e formular um critério para determinar quando um novo Gabinete se forma ${ }^{3}$. Defino a coalescência como uma variável contínua: quanto maior a proporcionalidade entre as cotas ministeriais dos partidos e seus pesos parlamentares, mais coalescente será o Ministério. Baseando-se nessa definição, a seção seguinte desenvolve um teste empírico para verificar se Gabinetes mais coalescentes estão associados a níveis mais elevados de disciplina legislativa dos partidos representados no Ministério.

Os gabinetes presidenciais podem funcionar como arranjos de coalizão à maneira dos sistemas parlamentaristas? Em princípio, sim. Mas não basta que políticos de pelo menos dois partidos façam parte do Ministério. Como afirmam Laver e Schofield (1990:130), para que haja uma coalizão é preciso existir um acordo que vincule (binding agreement) esses partidos. Mas esses dois autores estão pensando em sistemas parlamentaristas quando fazem tal afirmação, e os acordos de coalizão não funcionam da mesma maneira nos sistemas presidencialistas. Um presidente da República pode muito bem nomear ministros ligados a vários partidos, mas isso não significa que as legendas endossaram os nomes indicados; isto é, as nomeações não obrigam os respectivos partidos a apoiar o presidente no Legislativo (Mainwaring, 1993). Além disso, um presidente pode firmar um acordo com o partido A e outro com o partido B, sem que esses acordos comprometam um partido com o outro. Uma coisa é formar um Gabinete de coalizão, outra é administrar um governo de coalizão. Mesmo em um regime parlamentarista, um Gabinete de coalizão solidamente constituído pode dissolver-se em pouco tempo devido a conflitos inter e intrapartidários, e isso não quer dizer que o Ministério não era uma coalizão quando se formou. Assim, para evitar a confusão conceitual entre a formação de uma coalizão e a sua administração, proponho que a definição de Gabinete de coalizão em um sistema presidencialista se baseie simplesmente na existência de um acordo entre o presidente e mais de um partido em torno da nomeação de ministros. O problema passa então a ser o seguinte: será que o desenho de um acordo de coalizão influi na efetividade governativa da coalizão conforme evidenciado pelo comportamento legislativo dos partidos que compõem o Ministério? Este artigo propõe que a resposta é afirmativa, e argumenta que se os acordos de coalizão prevêem uma distribuição proporcional entre as cotas ministeriais e o peso parlamentar das legendas, os partidos coligados provavelmente se comportarão de modo disciplinado em relação às preferências do Executivo em votações nominais.

Como se pode verificar empiricamente que um acordo foi firmado? Seria necessário colher relatos históricos ou jornalísticos a respeito das negociações realizadas para definir os nomes que compuseram o Ministério. Mas esse procedimento seria muito demorado. De mais a mais, mesmo que um pesquisador 


\section{DADOS}

conseguisse reunir informações sobre a nomeação de todos os ministros, muitos acordos fixados entre os presidentes e os líderes partidários não seriam percebidos por causa do sigilo que costuma cercar as negociações políticas. O pesquisador teria de se basear no julgamento de outros para classificar alguns ministérios, e tal procedimento poderia resultar em juízos ad hoc que certamente prejudicariam a confiabilidade da análise.

Mas é possível evitar essas dificuldades fazendo algumas suposições plausíveis sobre o que constitui um acordo para a formação de um Gabinete e recorrendo unicamente às informações básicas disponíveis sobre os ministros: sua filiação partidária (se houver), data de nomeação e demissão, e o peso parlamentar do partido a que ele pertence. Faço, portanto, a suposição de que se um presidente e mais de um partido chegam a um acordo de coalizão em torno da composição do Gabinete, a distribuição das pastas ministeriais acompanha de modo mais ou menos proporcional o peso parlamentar de cada partido. Por esse raciocínio, a proporcionalidade das cotas ministeriais é uma solução de equilíbrio para os problemas de negociação que o presidente e os partidos enfrentam na partilha do poder Executivo ${ }^{4}$. De fato, estudiosos dos regimes parlamentaristas europeus têm mostrado empiricamente que as recompensas ministeriais dos partidos são dadas de acordo com o tamanho e o poder de barganha das legendas no Legislativo (Browne e Franklin, 1973; Budge e Keman, 1990:88-131; Laver e Schofield, 1990:164-194; Schofield e Laver, 1985). Proponho ainda que o grau de coalescência dos gabinetes presidenciais seja uma variável contínua; por isso, uso a norma de proporcionalidade como um padrão de comparação para identificar o grau de coalescência dos gabinetes. Alocações de cargos ministeriais que se desviem da norma da proporcionalidade devem ser vistas, portanto, como uma característica de ministérios com baixos níveis de coalescência. A pressuposição subjacente nesse caso é que quanto mais essas alocações se desviem da proporcionalidade, menos coalescente será o Gabinete.

Para explicar a relação entre cotas ministeriais e peso parlamentar, sugiro um indicador matemático, que denomino de Taxa de Coalescência do Gabinete (denominado Gabinete), e que se baseia no índice de proporcionalidade criado por Rose (1984) para medir a extensão do desvio da proporcionalidade entre cadeiras e votos produzido por uma dada eleição. Nesse estudo, ministérios e cadeiras substituem cadeiras e votos. A fórmula do indicador é a seguinte:

$$
\text { Gabinete }=1-1 / 2 \sum_{i=1}^{n}\left(\mid S_{i}-M_{i}\right)
$$

onde,

$\mathrm{M}_{\mathrm{i}}=\%$ de ministérios recebidos pelo partido i quando o Gabinete foi nomeado;

$\mathrm{S}_{\mathrm{i}}=\%$ de cadeiras ocupadas pelo partido i dentro do total de cadeiras controladas pelos partidos que integram o Gabinete quando este foi nomeado.

Para chegar à taxa de coalescência de um dado Gabinete, adiciono o valor absoluto da diferença entre o percentual de ministérios de cada partido e o percentual de cadeiras que cada partido controla do total de cadeiras controladas por todos os partidos que compõem o Gabinete, quer eles detenham cadeiras no Congresso ou não, e, no caso dos ministros, quer pertençam a um partido ou não, e depois divido o resultado por dois. Subtraindo o resultado de 1, obtenho a taxa de coalescência. 0 índice varia de zero (nenhuma correspondência entre a taxa de recompensas ministeriais e a porcentagem de cadeiras) a 1 , número que define o limite superior de correspondência perfeita entre cotas ministeriais e pesos legislativos dos partidos. Qualquer desvio desse limite superior é detectado. Para funcionar adequadamente, o índice exige que pelo menos um ministro seja ligado a um partido. Se todos os ministros fossem apartidários, o índice teria o valor de 0,5 , resultado que não é compatível com a definição de um Gabinete parcialmente de coalizão. Assim, no caso de um Ministério composto somente por políticos apartidários, o valor zero deve ser considerado a sua taxa de coalescência.

Os valores obtidos com esse índice exprimem a relação entre a informação que possui o pesquisador a porcentagem de ministros que pertencem a um determinado partido e o peso da bancada desse partido no total das cadeiras legislativas controladas pelas legendas partidárias que compõem o Ministério. Ou seja, Gabinete mede como a distribuição de postos ministeriais é ponderada em face da dispersão de cadeiras dentro do contingente parlamentar controlado pelos partidos que integram o Ministério. Suponhamos, por exemplo, a seguinte situação:

A Tabela 1 representa uma legislatura de cem cadeiras divididas entre três partidos, A, B e C, e um Gabinete composto de dez pastas. O presidente distribui duas pastas para o partido A, seis para o partido $\mathrm{C}$ e nomeia dois ministros independentes. A e C juntos controlam 65 cadeiras; portanto, $S_{a}$ é 0,31 (= $20 / 65), S_{c}$ é $0,69(=45 / 65)$ e cada um dos ministros independentes tem o valor zero em $S_{i}$. Em relação à porcentagem de pastas $\left(M_{i}\right)$, A tem $0,2, C, 0,6$ e cada ministro independente, 0,1 . A soma de todos os valores $\left|\mathrm{M}_{\mathrm{i}}-\mathrm{S}_{\mathrm{i}}\right|$ é 0,4 ; esse resultado dividido por 2 dá 0,2 , que subtraído de 1 resulta em 0,8 . Este valor nos diz que a distribuição de pastas nesse Gabinete se desvia da proporcionalidade perfeita, mas a correspondência entre cotas ministeriais e cadeiras legislativas ainda é alta. 


\section{DADOS}

Tabela 1

Exemplo Hipotético de como se Calcula a Taxa de Coalescência do Gabinete

\begin{tabular}{|l|l|l|l|l|}
\hline Partidos & $\begin{array}{l}\text { Cotas } \\
\text { Ministeriais }\end{array}$ & $\mathrm{S}_{\mathrm{i}}(\%)$ & $\mathrm{M}_{\mathrm{i}}(\%)$ & $\left|\mathrm{M}_{\mathrm{i}}-\mathrm{S}_{\mathrm{i}}\right|$ \\
\hline $\begin{array}{l}\text { A }= \\
\text { cadeiras }\end{array}$ & 20 & 0,31 & 0,2 & 0,11 \\
\hline $\begin{array}{l}\text { B = } \\
\text { cadeiras }\end{array}$ & & & & \\
\hline $\begin{array}{l}\text { C = } \\
\text { cadeiras }\end{array}$ & 6 & 0,69 & 0,6 & 0,09 \\
\hline & Independente & 0 & 0,1 & 0,1 \\
\hline Total = 100 & 10 pastas & & 0,1 & 0,1 \\
\hline
\end{tabular}

Taxa de Coalescência do Gabinete $=1-1 / 2 * 0,4=1-0,2=0,8$

Embora Gabinete capte muitas informações, existem dois problemas com esse índice. Primeiro, deve-se notar que ele presume que todos os postos ministeriais são do mesmo valor. Porém, no mundo real da política as coisas não são assim: alguns ministérios são mais importantes do que outros. O Ministério da Fazenda é um bom exemplo. Entretanto, qualquer método que se use para quantificar os diversos valores políticos dos cargos ministeriais será sempre de baixa confiabilidade e passível a críticas. Por exemplo, se usássemos as dotações orçamentárias destinadas aos ministérios para medir o valor político de cada um, um cargo muito valorizado como o de ministro das Relações Exteriores obteria um grau muito baixo no Brasil, em particular, e na América Latina, em geral. Portanto, embora reconhecendo que o suposto de um mesmo valor político para todos os ministérios é uma solução imperfeita, sustento que é mais confiável do que qualquer tentativa de quantificar esse valor.

Segundo, Gabinete supõe que o poder de barganha de um partido é diretamente proporcional ao tamanho de sua bancada parlamentar. Em certas circunstâncias é possível que um partido pequeno consiga exigir uma representação no Ministério superior ao seu peso legislativo para participar deste. Isso pode ocorrer em regimes parlamentaristas puros nos quais a sobrevivência do governo depende da tolerância dos partidos representados no Parlamento. Mas em sistemas presidencialistas puros, como é o caso do Brasil, a capacidade dos partidos pequenos de arrancar concessões desproporcionais ao seu peso político é muito reduzida devido ao prazo fixo do mandato presidencial.

\section{Reformas Ministeriais}

Em um sistema presidencialista puro, a Constituição concede aos presidentes o direito de demitir seus ministros quando quiserem. Por isso, no decorrer de um mandato presidencial, podem ser formados novos gabinetes. Como os identificamos? Adoto três critérios para distinguir um novo Gabinete presidencial:

(1) a posse de um novo presidente;

(2) uma mudança na composição partidária do Gabinete;

(3) uma mudança na identidade de mais da metade dos ministros.

O primeiro critério é óbvio. Nos sistemas presidencialistas, a posse de um novo presidente representa uma mudança total no Executivo porque este poder é inteiramente investido no chefe de Estado. $O$ segundo critério é necessário pois Gabinete enfatiza a composição partidária do Executivo e qualquer modificação nesse perfil constitui forçosamente um novo Gabinete. Acrescentei o terceiro critério porque, em um sistema presidencialista, os membros do Ministério devem gerir suas pastas em consonância com os objetivos do presidente, e, portanto, uma mudança importante no nome dos ministros também pode significar uma grande modificação na maneira como o presidente deseja conduzir o Executivo e no modo como ele se relaciona com os partidos e com o poder Legislativo. 


\section{DADOS}

Os Militares no Gabinete

Finalmente, considero os militares de alta patente, que em regra são designados para chefiar os ministérios do Exército, Marinha e Aeronáutica no Brasil, como ministros independentes. Mas apenas incluo nos cálculos o Ministro do Exército. Essa simplificação visa evitar uma superestimação dos ministros não vinculados a partidos.

Gabinetes Presidenciais no Brasil

A Tabela 2 apresenta a taxa de coalescência e outros indicadores para os ministérios formados pelos quatro últimos presidentes da República no Brasil, no período de 1985 a 1999. Os dados mostram uma substancial variação nas taxas de coalescência, que variam de um mínimo de 0,22 (no quinto Ministério de Itamar Franco) até um máximo de 0,62 (no primeiro Gabinete de Itamar). As taxas de coalescência dos últimos ministérios de Sarney e Itamar e daqueles nomeados por Collor não permitem classificá-los como gabinetes de coalizão, enquanto o primeiro Ministério de Sarney e os dois gabinetes do primeiro governo de Fernando Henrique se enquadram com certeza nessa definição. Na próxima seção, faço uma breve recapitulação da estrutura institucional do presidencialismo brasileiro a fim de estabelecer suas relações com a política de formação de gabinetes.

\section{A ESTRUTURA INSTITUCIONAL DO PRESIDENCI ALISMO NO BRASIL}

Em março de 1985, tomou posse um presidente civil, escolhido por um Colégio Eleitoral formado pelos membros do Congresso Nacional e seis representantes de cada Assembléia estadual, após 21 anos de ditadura militar e de uma longa transição iniciada em 1974. Um dos primeiros atos do novo regime foi conferir poderes constituintes ao Congresso a ser eleito em novembro de 1986. Este Congresso Constituinte, instalado em fevereiro de 1987, somente conseguiu promulgar um novo texto constitucional em outubro de 1988. Por esse motivo, entre março de 1985 e outubro de 1988, o sistema político funcionou dentro das regras da Constituição de 1967 e de emendas posteriores outorgadas pelos militares. Estas regras instituíam um regime presidencialista puro e forte, que dava ao presidente da República o controle total do Executivo e lhe conferia o poder de governar por decreto, praticamente isento dos entraves representados pelos controles do poder Legislativo (Pessanha, 1997, cap. 3). Caso o Congresso não deliberasse sobre os decretos dentro de um prazo de sessenta dias, eles eram considerados automaticamente aprovados.

Com a promulgação da Constituição de 1988, o presidencialismo brasileiro passou a ter as seguintes características ${ }^{5}$ : o presidente é eleito por maioria absoluta, havendo uma eleição de segundo turno entre os dois candidatos mais votados no primeiro turno, caso nenhum deles obtenha $50 \%$ do total de votos válidos. De 1985 a 1994, o mandato presidencial foi de cinco anos. Em 1994, esse prazo foi reduzido para quatro anos. Em junho de 1997, o Congresso aprovou, pela primeira vez em sua história, uma emenda constitucional que permitia uma reeleição imediata para a Presidência da República. A Constituição de 1988 concede ao chefe do Executivo o poder de opor veto parcial e total aos projetos de lei; a faculdade de propor leis, com o monopólio da iniciativa em muitas áreas de políticas públicas; o poder de nomear e demitir ministros livremente; e a prerrogativa de editar medidas provisórias com imediata força de lei. As medidas provisórias devem ser imediatamente submetidas ao Congresso, e caso não sejam convertidas em lei no prazo de trinta dias, perdem eficácia. Embora o Artigo 62 da Constituição estabeleça que as medidas provisórias somente podem ser editadas em matérias de urgência e relevância, na realidade elas converteram-se no instrumento político mais usado pelos presidentes, principalmente para implementar decisões de política econômica. Figueiredo e Limongi (1997:144) mostram que no período de 1988 a 1995 foram editadas 1.249 medidas provisórias. Cabe assinalar, porém, que, deste total, 862 medidas eram versões repetidas de decretos não analisados pelo Congresso no prazo de trinta dias após sua emissão. Uma taxa tão elevada de medidas provisórias reeditadas é um sinal claro de que essa arma constitucional estimula os presidentes a uma ação unilateral e ao abuso dos seus poderes legislatórios (Power, 1998) $\underline{\text {. }}$.

\section{Multipartidarismo}

Um aspecto decisivo nas relações entre Executivo e Legislativo em qualquer sistema político democrático é a distribuição partidária do poder na esfera legislativa. Segundo um trabalho acerca de 54 democracias (Amorim Neto e Cox, 1997:169-170), o Brasil possuía na década de 80 um dos Legislativos mais fragmentados do mundo. Na opinião de muitos analistas, um nível tão elevado de fragmentação mutila a capacidade decisória do sistema político (Lamounier, 1994; Mainwaring, 1997), prejudicando seriamente as perspectivas da consolidação democrática. Para medir a fragmentação do Legislativo, uso o índice convencional de número efetivo de partidos, de Laakso e Taagepera (1979). A fórmula é a seguinte:

$\mathrm{N}=1 / \mathrm{x}^{2}$

onde, 


\section{DADOS}

$\mathrm{x}_{\mathrm{i}}=$ percentual de cadeiras controladas pelo enésimo partido com representação na Câmara dos Deputados.

A Tabela 3 apresenta o número efetivo de partidos representados no Congresso no Brasil no período de 1985 a 1999.

Tabela 3

Número Efetivo de Partidos com Representação Parlamentar (1985-1999)

\begin{tabular}{|l|l|l|l|l|l|l|l|l|l|l|l|l|l|l|l|}
\hline 1985 & 1986 & $1987 *$ & 1988 & 1989 & 1990 & $1991 *$ & 1992 & 1993 & 1994 & $1995^{*}$ & 1996 & 1997 & 1998 & $1999 *$ \\
\hline 3,2 & 3,3 & 2,8 & 4,1 & 5,5 & 7,1 & 8,7 & 9,4 & 8,5 & 8,2 & 8,1 & 7,1 & 6,9 & 6,8 & 7,1 \\
\hline
\end{tabular}

Fontes: Nicolau (1996:72); Folha de S. Paulo, "O Novo Congresso", 10/10/1998, p. 1; Folha de S. Paulo, "A Nova Câmara dos Deputados", Caderno Especial "Eleições 1998", 10/10/1998, p. 2; além de dados fornecidos por Bolívar Lamounier.

* Primeiro ano de uma nova legislatura eleita no ano anterior.

No período mencionado, a fragmentação da Câmara dos Deputados quase triplicou (de 3,2 passou para 9,4). É verdade que houve uma diminuição entre 1986 e 1987, e que a taxa se estabilizou entre 1996 e 1999, mas a tendência principal na totalidade do período foi de um dramático aumento da fragmentação. Entre 1985 e 1999, o tamanho médio do partido do presidente foi de 12,3\% das cadeiras na Câmara. Essa alta fragmentação resultou da combinação de dois fatores: declínio eleitoral dos dois maiores partidos do período militar (o Partido Democrático Social PDS e o Partido do Movimento Democrático Brasileiro PMDB) e migração sem restrições de deputados federais entre os partidos (Lima Junior, 1993; Nicolau, 1996) $)^{\underline{7}}$.

De que maneira a fragmentação do Legislativo afeta o presidencialismo? Muitos autores já analisaram essa questão (Mainwaring, 1993; Mainwaring e Shugart, 1997; Jones, 1995) e suas conclusões geralmente coincidem: quanto maior a fragmentação legislativa, menor é o tamanho do partido do presidente. Os dados acima apresentados mostram que o Brasil é um eloqüente exemplo disso.

Como a estrutura institucional do presidencialismo se relaciona com a formação de coalizões no Brasil? Analisando dados sobre 75 ministérios nomeados por 57 presidentes em dez países latino-americanos no período 1946-1995, Amorim Neto (1998, cap. 3) demonstrou que a coalescência do Gabinete é uma função positiva do tamanho do partido do presidente e uma função negativa do poder constitucional do presidente de editar decretos-leis. Quanto maior é o tamanho do partido do presidente, mais alto é o valor de Gabinete. O poder de editar decretos, por sua vez, reduz o valor da taxa de coalescência. O nexo entre tamanho do partido do presidente e taxa de coalescência do Gabinete está no fato de que, na maioria das vezes, os presidentes com forte respaldo partidário tendem a executar políticas pela via legislativa normal. Por isso, compõem gabinetes de coalizão com vistas a consolidar sua base de apoio no Legislativo. Os presidentes que têm fraco apoio partidário preferem outras estratégias à via regulamentar para a adoção de políticas. Portanto, usam a nomeação de ministros para outros fins, entre os quais, recompensar os amigos ou recrutar especialistas para o governo. De modo análogo, os presidentes que têm poder de decreto preferem recorrer a este instrumento unilateral de decisão, prescindindo, portanto, de níveis elevados de coalescência do Gabinete. Contrariamente ao período 1946-1964, todos os presidentes brasileiros entre 1985 e 1999 tiveram o poder de emitir medidas provisórias e, por isso, boa parte da variação de Gabinete neste último período é explicada pelo tamanho do partido do presidente. Por exemplo, os níveis baixos de coalescência dos ministérios de Collor explicam-se em parte pelo fato de que seu partido controlava uma parcela muito pequena de deputados na Câmara dos Deputados.

\section{O IMPACTO DOS GABI NETES PRESIDENCIAIS EM VOTAÇÕES LEGISLATIVAS}

Para analisar o impacto de Gabinete na disciplina legislativa dos partidos que integram o Ministério, precisamos encontrar uma medida válida para disciplina. Os deputados agem disciplinadamente quando os membros da mesma coalizão atuam com um alto grau de unidade. Há duas importantes arenas legislativas em que o comportamento de coalizões pode ser observado com facilidade: as comissões e o Plenário. O segundo é certamente mais relevante porque as decisões tomadas no Plenário freqüentemente significam a última palavra da Assembléia sobre alguma matéria. Ademais, as decisões feitas por este requerem um número maior de deputados do que as que são tomadas pelas comissões. Isto é, o Plenário é uma amostra mais representativa do conjunto da legislatura do que as comissões.

O Plenário também é a melhor arena para observar até que ponto os arranjos de coalizão para a formação do Gabinete realmente vinculam os partidos na Câmara. Vejamos uma comparação entre os regimes presidencialista e parlamentarista. Em primeiro lugar, nos sistemas presidencialistas é mais 


\section{DADOS}

difícil obter cooperação entre os poderes do que nos regimes parlamentaristas. Isso se explica, em última análise, pela cláusula que determina o mandato fixo do presidente e da Assembléia e estabelece que o chefe do Executivo não precisa renunciar no caso de uma derrota no Legislativo de um projeto patrocinado pelo governo, nem a Assembléia pode ser dissolvida na ocorrência de um impasse entre os dois poderes. Por isso, os membros dos partidos governistas nos sistemas presidencialistas sentem-se mais livres para votar contra o Executivo no Plenário da Câmara do que seus colegas nos regimes parlamentaristas. Se estes últimos desejarem fazê-lo, o primeiro-ministro sempre pode recorrer à ameaça de renúncia, o que acarreta a convocação de uma eleição antecipada cujas conseqüências poderiam muito bem ser uma derrota dos partidos governistas. Antevendo essa possibilidade, os parlamentares pertencentes à base do governo geralmente preferem transferir seus eventuais conflitos com o Gabinete para arenas externas ao Parlamento. Isso põe nas mãos dos primeiros-ministros uma poderosa arma para induzir a aquiescência dos parlamentares no que concerne exclusivamente ao seu comportamento em Plenário. É por isso que nos sistemas parlamentaristas as decisões tomadas por votação nominal são altamente previsíveis, pois a última palavra costuma caber à posição definida pelo Gabinete. Somente em raras e extraordinárias ocasiões, o "baixo clero" vota contra o governo no Plenário do Parlamento.

Por essa lógica, as votações nominais não proporcionam as melhores evidências para uma análise da disciplina legislativa nos sistemas parlamentaristas. Nesses regimes, a disciplina ou o conflito legislativo são melhor observados nas convenções e reuniões de bancadas e ministeriais onde se articula a linha do partido e onde opiniões divergentes podem ser enunciadas com mais liberdade. Em arenas desse tipo, quase sempre se chega a uma solução de compromisso entre as posições do Ministério e a dos parlamentares, de modo que os projetos levados ao Plenário correm poucos riscos de derrota. Porém, uma característica das votações nominais na maioria dos regimes presidencialistas, principalmente naqueles em que a disciplina não é muito rígida, como no Brasil e nos Estados Unidos, é a incerteza, pelas razões que acabo de expor. A separação dos poderes coloca os presidentes diante de um sério problema de cumprimento de acordos em suas tratativas com os deputados, o que evidentemente se reflete no comportamento no Plenário. Em virtude desse fato e da disciplina imperfeita dos partidos políticos brasileiros, usarei as votações nominais para examinar o impacto legislativo dos gabinetes presidenciais.

Cabe fazer algumas observações sobre as normas que regulam as votações nominais no Brasil. De acordo com o regimento da Câmara dos Deputados, decisões em Plenário podem ser feitas por três métodos: votação secreta, simbólica e nominal. A votação secreta exige um quorum de dois terços, e destina-se a deliberar sobre a criação de comissões de inquérito e sobre processos de impeachment de presidentes, parlamentares e juízes. A votação simbólica é o método mais usual de decisão. Para ter validade, exige-se a presença no Plenário de metade mais um do total dos deputados da Casa. Mas a votação pode realizar-se sem que a mesa diretora verifique a presença de uma maioria de parlamentares. Contudo, se concluída a tomada de votos, alguns deputados acharem que o quorum mínimo não foi atingido, eles podem pedir uma contagem deste. Todo pedido de verificação de quorum apoiado por no mínimo $6 \%$ da totalidade dos membros da Câmara é motivo para a realização de uma votação nominal.

Por conseguinte, no Brasil, a votação nominal proporciona aos deputados de oposição uma oportunidade de tornar as decisões feitas pelas maiorias mais custosas pois as opiniões têm de ser reveladas publicamente, ao contrário das votações simbólicas e mais demoradas pois a maioria tem de repetir-se duas vezes para o projeto ser aprovado. Assim, a votação nominal é um importante instrumento de obstrução nas mãos da oposição. Portanto, essas votações constituem um bom locus para o exame do conflito partidário e da disciplina legislativa, principalmente no Brasil ${ }^{\underline{8}}$.

Os Dados

Analisei todas as votações nominais realizadas na Câmara dos Deputados entre 1989 e 1998 para as quais havia informações sobre as preferências do presidente da República. A razão de levar em conta somente esse tipo de votação é simples de entender: como o objetivo desta seção é verificar até que ponto deputados filiados aos partidos que integram o Gabinete presidencial se comportam de modo disciplinado, as votações que trazem alguma informação sobre a agenda presidencial são as mais válidas. No Brasil, identificar as preferências do presidente é muito fácil por causa da regra que autoriza o chefe do Executivo a nomear um líder do governo na Câmara. O papel deste líder é informar os parlamentares e líderes de partido a posição do presidente a respeito das matérias em discussão, e negociar com esses interlocutores. Antes de se iniciar uma votação nominal, o presidente da Câmara pergunta ao líder do governo qual a posição do Executivo relativa à matéria a ser votada. 


\section{DADOS}

No período de 1989 a 1998, houve 420 votações nominais para as quais havia informações acerca da posição do líder do governo. Esse período cobre os últimos dois anos da legislatura de 1987-1990; todo o mandato das legislaturas de 1991-1994 e 1995-1998; o último ano do governo Sarney; todo o período presidencial de Collor e Itamar; o primeiro governo de Fernando Henrique.

\section{A Variável Dependente: Disciplina Legislativa dos Partidos Representados no Gabinete}

Defino disciplina legislativa como o grau de unidade com que os partidos se conduzem em votações nominais (denomino-a de Disciplina). Como meu foco de interesse é o comportamento dos partidos que têm membros seus participando do Ministério, meço a disciplina legislativa da seguinte forma:

Disciplina $=\%$ da totalidade da bancada dos partidos representados no Ministério que votam de acordo com a orientação do líder do governo em cada votação nominal

Convém notar que essa medida supõe que a abstenção e a ausência também são formas de comportamento não cooperativo com o governo. Se considerássemos que a única forma de comportamento não cooperativo dos deputados federais com o líder do governo fosse votar abertamente contra a orientação deste ( $p$. ex., quando o líder recomenda que os deputados votem sim e um deputado pertencente a um dos partidos do Ministério vota não, ou vice-versa), estaríamos superestimando a disciplina legislativa da coalizão.

Suponhamos, por exemplo, um Gabinete formado pelos partidos A, B e C. O partido A tem sessenta deputados; o partido B, trinta e o partido C, dez. Em uma determinada votação nominal, 54 deputados do partido A comparecem, 37 votam sim e 17 votam não; no partido B, comparecem 24 deputados, dos quais 20 votam sim e 4 não; no partido C, 8 estiveram presentes à votação e destes 4 votam sim e 4 não. Suponhamos ainda que a posição do líder do governo é conhecida e que sua recomendação era para votar sim. Se descontarmos as abstenções e os ausentes, a disciplina legislativa dos partidos presentes no Gabinete nessa votação nominal será: $(37+20+4) /(54+24+8)=61 / 86=0,71$. Mas se incluirmos no denominador as abstenções e ausências, a taxa de disciplina legislativa será: $(37+20+$ $4) /(60+30+10)=61 / 100=0,61$.

Finalmente, conforme assinalaram vários autores (Bond e Fleisher, 1990; Carey, 1999; Figueiredo e Limongi, 1995; Mainwaring e Pérez Liñán, 1998; Riker, 1959), nem todas as votações nominais são significativas para se avaliar o comportamento legislativo e o conflito partidário. As votações em que há consenso ou quase consenso são menos importantes do que aquelas em que a vitória se dá por uma pequena margem. Analogamente, pode-se dizer que as votações nominais em que o comparecimento é baixo são menos relevantes do que aquelas em que houve uma presença maciça de deputados. Por esse motivo, é conveniente definir critérios claros de relevância para as votações nominais, levando em conta simultaneamente quão apertada foi a votação e a taxa de comparecimento dos deputados. Escolhi definir um ponto de corte baseado no indicador "relevância de uma votação nominal" ou "critical-ness", conforme proposto por Carey (1999). A fórmula é a seguinte:

Relevância = Comparecimento*Margem

onde,

Comparecimento $=\%$ dos deputados que votaram;

Margem $=1-(2 *|0,5-\% \operatorname{Sim}|)$;

$\% \operatorname{Sim}=\mathrm{N}$ de Sim/ totalidade dos membros da Câmara dos Deputados.

Somente foram incluídas votações em que pelo menos 0,6 dos deputados votaram e no mínimo 0,2 dos votos foram dados contra a maioria. Inserindo esses valores na fórmula acima, chegamos ao seguinte valor de Relevância:

Relevância $=0,6 *[1-(2 *|0,5-0,8|)]=0,6 *[1-0,6]=0,6 * 0,4=0,24$

Isso significa que para ser selecionada, uma votação nominal tem de alcançar o valor de 0,24 no indicador de Carey 9 . Aplicando o ponto de corte de 0,24, a amostra final foi reduzida a 324 votações nominais significativas. A Tabela 4 mostra a média e o desvio-padrão de Disciplina, por Gabinete, junto com a taxa de apoio de cada partido ao presidente (variável cuja definição será explicada na próxima seção).

Tabela 4

Resumo Estatístico sobre Disciplina Legislativa e Apoio ao Presidente

por Gabinete no Brasil (1985-1998)

\begin{tabular}{|l|l|l|ll|l|l|}
\hline $\begin{array}{l}\text { Presidente } \\
\text { e } \\
\text { Gabinete }\end{array}$ & $\begin{array}{l}\text { No de } \\
\text { Votações } \\
\text { Nominais }\end{array}$ & $\begin{array}{l}\text { Disciplina } \\
\text { Legislativa }\end{array}$ & $\begin{array}{l}\text { Apoio do } \\
\text { PMDB } \\
\text { Presidente }\end{array}$ & $\begin{array}{l}\text { apoio do PFL } \\
\text { ao Presidente }\end{array}$ & $\begin{array}{l}\text { Apoio do PSDB } \\
\text { ao Presidente }\end{array}$ \\
\hline
\end{tabular}


DADOS

\begin{tabular}{|l|l|l|l|l|l|l|l|l|l|}
\hline & & Média & $\begin{array}{l}\text { Desvio } \\
\text { Padrão }\end{array}$ & Média & $\begin{array}{l}\text { Desvio } \\
\text { Padrão }\end{array}$ & Média & $\begin{array}{l}\text { Desvio } \\
\text { Padrão }\end{array}$ & Média & $\begin{array}{l}\text { Desvio } \\
\text { Padrão }\end{array}$ \\
\hline Sarney I & s.i. & s.i. & s.i. & s.i. & s.i. & s.i. & s.i. & s.i. & s.i. \\
\hline Sarney II & s.i. & s.i. & s.i. & s.i. & s.i. & s.i. & s.i. & s.i. & s.i. \\
\hline Sarney III & 4 & 0,52 & 0,26 & 0,46 & 0,25 & 0,65 & 0,30 & 0,19 & 0,27 \\
\hline & & & & & & & & & \\
\hline Collor I & 18 & 0,63 & 0,17 & 0,53 & 0,21 & 0,73 & 0,21 & 0,35 & 0,31 \\
\hline Collor II & 41 & 0,51 & 0,19 & 0,45 & 0,25 & 0,55 & 0,21 & 0,35 & 0,30 \\
\hline Collor III & 1 & 0,55 & - & 0,02 & - & 0,60 & - & 0,00 & - \\
\hline Collor IV & 8 & 0,63 & 0,13 & 0,34 & 0,29 & 0,65 & 0,29 & 0,25 & 0,30 \\
\hline & & & & & & & & & \\
\hline Itamar I & 10 & 0,70 & 0,10 & 0,76 & 0,10 & 0,65 & 0,14 & 0,83 & 0,11 \\
\hline Itamar II & 11 & 0,54 & 0,20 & 0,60 & 0,21 & 0,42 & 0,27 & 0,70 & 0,22 \\
\hline Itamar III & 13 & 0,55 & 0,19 & 0,60 & 0,24 & 0,49 & 0,23 & 0,66 & 0,25 \\
\hline I tamar IV & 1 & 0,44 & - & 0,50 & - & 0,33 & - & 0,58 & - \\
\hline I tamar V & 2 & 0,48 & 0,08 & 0,50 & 0,01 & 0,35 & 0,19 & 0,81 & 0,06 \\
\hline FHC I & 82 & 0,71 & 0,16 & 0,64 & 0,17 & 0,75 & 0,19 & 0,77 & 0,18 \\
\hline & 133 & 0,70 & 0,12 & 0,63 & 0,15 & 0,77 & 0,12 & 0,77 & 0,13 \\
\hline
\end{tabular}

Fonte: Dados sobre votações nominais fornecidos por Argelina C. Figueiredo, Fernando Limongi e Jairo Nicolau.

Obs.: s.i. = sem informação.

A Principal Variável Independente: Taxa de Coalescência do Gabinete

A hipótese principal a ser testada neste trabalho é a seguinte:

H1. Quanto mais coalescente for o Gabinete, mais disciplinado será o comportamento dos deputados que pertencem aos partidos integrantes do Ministério nas votações nominais.

A razão desta hipótese é que um Gabinete que tem uma taxa elevada de coalescência reflete uma distribuição judiciosa dos postos ministeriais entre os partidos. Uma alocação desse tipo provavelmente levará os partidos integrantes do Gabinete a apoiarem o Executivo de modo mais consistente. Por esse motivo, espero que a taxa de coalescência tenha um sinal positivo nas equações de regressão.

Outras Variáveis Independentes Relevantes: O Decurso do Mandato Presidencial e a Abrangência Ideológica do Gabinete

A taxa de coalescência do Gabinete supõe que os partidos são atores que buscam maximizar a ocupação de cargos. No entanto, Strom (1990) formulou o convincente argumento de que os partidos têm outros interesses fundamentais: a maximização de votos e a consecução de objetivos programáticos.

De que maneira o voto e a consecução de objetivos programáticos influem na disciplina legislativa no contexto da política brasileira?

Uma vez que, nos regimes presidencialistas puros, o mandato do presidente da República é fixo, com o decorrer desse prazo, o valor atribuído pelos partidos à ocupação de postos ministeriais diminui, pois o interesse em ocupar cargos cede lugar à maximização de votos (Altman, 1998; Amorim Neto e Santos, no prelo). De acordo com esse raciocínio, é provável que surjam correntes de oposição mais fortes no interior das bancadas parlamentares dos partidos que integram o Gabinete à medida que o prazo do mandato presidencial se vai esgotando. E com isso, a unidade da coalizão provavelmente também diminui com o passar do tempo. Assim, minha segunda hipótese é a seguinte:

H2. A disciplina legislativa nas votações nominais diminui com o decorrer do mandato presidencial.

Para operacionalizar a variável decurso do mandato presidencial, faço uma contagem simples da distância temporal, em dias, entre a data em que se realizou a votação nominal e a data constitucional do término do governo (denomino essa variável de Decurso). 


\section{DADOS}

Decurso $=T_{f}-T_{v}$

onde,

$\mathrm{T}_{\mathrm{f}}=\mathrm{o}$ dia em que termina o mandato do presidente;

$T_{v}=o$ dia em que se realizou a votação nominal.

Por exemplo, se a votação nominal de um projeto se deu no 90 이 dia de um mandato presidencial de cinco anos (que corresponde a 1825 dias), o valor desta votação na variável Decurso é de $1825-90=1735$. Suponho que essa variável tenha um sinal positivo, quer dizer, no início de um mandato presidencial, quando a distância entre os dias em que se realizam votações nominais e a data prevista para o fim do período presidencial é maior, a unidade da coalizão deve alcançar valores mais altos.

E quanto aos interesses programáticos? Embora os maiores partidos brasileiros (aqueles que costumam compor os ministérios) geralmente sejam considerados como organizações clientelistas, eles também têm perfis ideológicos identificáveis (Figueiredo e Limongi, 1995; Kinzo, 1993; Mainwaring, 1999: 88135), que influem nas estratégias de coligação eleitoral dos partidos (Schmitt, 1999) e em seu comportamento legislativo (Figueiredo e Limongi, 1995). Se essa afirmação for verdadeira, a diversidade ideológica do Gabinete deveria repercutir na disciplina legislativa dos partidos presentes no Gabinete. Ministérios formados por partidos ideologicamente muito diferentes devem ter níveis mais baixos de disciplina legislativa do que aqueles constituídos por parceiros mais homogêneos. Por exemplo, um Gabinete composto de dois partidos de centro (uma coalizão altamente homogênea) provavelmente terá taxas mais elevadas de disciplina legislativa do que um outro formado por três partidos, um de centro, um de centro-direita e o terceiro de centro-esquerda ${ }^{10}$. Isso porque é muito mais difícil coordenar as preferências dos partidos que compõem o Gabinete no segundo caso do que no primeiro. Minha terceira hipótese, então, é a seguinte:

H3. Quanto mais diversificado ideologicamente for um Gabinete, menor será a disciplina legislativa nas votações nominais.

Para operacionalizar a variável diversidade ideológica do Ministério, meço a distância ideológica entre o partido mais à esquerda e o mais à direita no Gabinete (denomino essa variável de Abrangência). Como medi-la? Seguindo as sugestões de Coppedge (1997) e Mainwaring (1999), suponho que a mais importante clivagem a separar os partidos brasileiros é a clássica divisão esquerda-direita. Ambos os autores citados localizam os partidos brasileiros nas cinco posições-padrão da escala esquerda-direita, a saber, esquerda, centro-esquerda, centro, centro-direita e direita $\underline{11}$. Adotando um procedimento semelhante ao de Coppedge, proponho ainda que a distância entre cada posição contígua seja de 0,5. Portanto, se um Gabinete é composto por um partido de centro, outro de centro-esquerda e um terceiro de centro-direita, seu valor na variável Abrangência equivale à distância entre os dois últimos partidos, isto é, 1,0. Abrangência varia de 0 a 2,0, sendo 0 o valor para todos os gabinetes cujos partidos ocupam a mesma posição ideológica e 2,0, o valor para todos os gabinetes que incluem um partido de esquerda e outro de direita.

Abrangência $=\left|P_{m e}-P_{m d}\right|$

onde,

$\mathrm{P}_{\mathrm{me}}=$ a posição ideológica na escala esquerda-direita do partido mais à esquerda representado no Gabinete;

$P_{m d}=$ a posição ideológica na escala esquerda-direita do partido mais à direita representado no Gabinete. Note-se que Abrangência é um indicador imperfeito de diversidade ideológica porque não considera o percentual de postos ministeriais correspondente a cada bloco ideológico representado no Gabinete. Uma medida ideal deveria incluir tanto as posições ideológicas quanto o percentual de postos ministeriais controlados por todos os blocos ideológicos representados no Gabinete, tal como Coppedge (1998) calcula o número efetivo de blocos ideológicos nos sistemas partidários da América Latina. Mas é impossível aplicar essa medida no Brasil por causa da elevada proporção de ministros sem partido que fazem parte dos gabinetes. O único método confiável para identificar a posição ideológica de ministros sem partido é a realização de surveys com especialistas; infelizmente, não existem tais surveys sobre a posição ideológica dos ministros brasileiros.

A Tabela 2 mostra que no período de 1985 a 1999 nenhum Gabinete foi totalmente composto apenas com ministros partidários e em muitos casos a porcentagem dos ministros sem partido foi muito alta. Por exemplo, no último Ministério de Itamar, $76 \%$ dos ministros não pertenciam a partido algum; os três primeiros gabinetes de Collor tinham uma porcentagem de $60 \%$ de ministros sem partido e nos dois ministérios do primeiro mandato de Fernando Henrique havia $32 \%$ de ministros nessa situação. Uma forma de reduzir o erro de não computar a porcentagem de postos ministeriais de cada posição ideológica representada no Gabinete é calcular Abrangência apenas para os partidos que controlam mais de uma pasta ou um mínimo de $5 \%$ das cadeiras da Câmara dos Deputados. É melhor usar critérios arbitrários mas plausíveis de relevância do que superestimar o peso dos partidos nanicos na diversidade ideológica do Gabinete. Recordemos a definição de Abrangência: trata-se de uma medida da distância 


\section{DADOS}

ideológica entre os partidos mais à esquerda e mais à direita que compõem o Ministério e que satisfazem aos dois critérios de relevância. A Tabela 2 apresenta os resultados de Abrangência para todos os gabinetes do governo federal no período 1985-1999.

Levando tudo em conta, a equação de regressão resultante toma a seguinte forma:

Disciplina $=$ ß0 +ß1Gabinete + ß2Decursoß3Abrangência + (eq.1)

Resultados

A Tabela 5 apresenta os resultados da regressão. No Modelo 1, o modelo completo, tanto Gabinete quanto Decurso foram significantes no nível 0,01 , no teste de uma cauda. Abrangência não foi estatisticamente discernível de zero e teve o sinal errado. Usei, então, um segundo modelo, que excluiu Abrangência do lado direito da equação. Gabinete e Decurso permaneceram significantes no mesmo nível do primeiro modelo. Em um terceiro modelo, excluí Decurso; Gabinete continuou significante no nível 0,01 e Abrangência, mais uma vez, não se mostrou significante, obtendo também o sinal errado. Verifiquei a existência de um problema de multicolinearidade com Abrangência, correlacionando-a com Gabinete e Decurso. Encontrei uma alta correlação entre Abrangência e Gabinete (de 0,75). Apliquei então um quarto modelo que excluiu Gabinete do lado direito da equação. Decurso não foi significante, mas, pela primeira vez, Abrangência mostrou ter significância relativamente à disciplina legislativa, apesar de novamente aparecer com o sinal errado.

Tabela 5

Os Determinantes da Taxa de Disciplina Legislativa (em Consonância com as Preferências do Presidente) dos Partidos que Participam do Gabinete (1989-1998) ${ }^{1}$

\begin{tabular}{|c|c|c|c|c|}
\hline \multicolumn{5}{|c|}{$\begin{array}{l}\text { Variável Dependente: Disciplina Legislativa dos Partidos que participam do } \\
\text { Gabinete }\end{array}$} \\
\hline $\begin{array}{l}\text { Variáveis } \\
\text { Independentes }\end{array}$ & Modelo 1 & Modelo 2 & Modelo 3 & Modelo 4 \\
\hline Constante & $\begin{array}{l}0,107 \\
(0,083)\end{array}$ & $\begin{array}{l}0,094 \\
(0,079)\end{array}$ & $\begin{array}{l}0,258 * * * \\
(0,066)\end{array}$ & $\begin{array}{l}0,503 * * * \\
(0,039)\end{array}$ \\
\hline Gabinete & $\begin{array}{l}0,874 * * * \\
(0,164)\end{array}$ & $\begin{array}{l}0,930 * * * \\
(0,122)\end{array}$ & $\begin{array}{l}0,727 * * * \\
(0,158)\end{array}$ & \\
\hline Decurso & $\begin{array}{l}0,00007 * * * \\
(0,00002)\end{array}$ & $\begin{array}{l}0,00008 * * * \\
(0,00002)\end{array}$ & & $\begin{array}{l}0,00003 \\
(0,00002)\end{array}$ \\
\hline Abrangência & $\begin{array}{l}0,012 \\
(0,024)\end{array}$ & & $\begin{array}{l}0,003 \\
(0,024)\end{array}$ & $\begin{array}{l}0,098 * * * \\
(0,019)\end{array}$ \\
\hline $\begin{array}{l}\mathrm{R}^{2} \text { Ajustado } \\
\mathrm{N} \text { o de Observações }\end{array}$ & $\begin{array}{l}0,151 \\
324\end{array}$ & $\begin{array}{l}0,153 \\
324\end{array}$ & $\begin{array}{l}0,130 \\
324\end{array}$ & $\begin{array}{l}0,078 \\
324\end{array}$ \\
\hline $\begin{array}{lr}\text { s } & \text { erros-pa } \\
01 ; * * & >0,05 ; *\end{array}$ & ão & stão & ndicados & entre \\
\hline
\end{tabular}

Como trabalhei com dados de séries temporais, testei a existência de autocorrelação pela regressão de resíduos não padronizados nas suas variáveis de intervalo e em todas as outras variáveis explicativas para os quatro modelos. Nenhum problema de autocorrelação foi detectado.

Por que Abrangência não obteve significância? Provavelmente porque é uma medida muito crua, de modo que somente quando houver disponibilidade de um indicador mais refinado será possível verificar corretamente o impacto da diversidade ideológica dos gabinetes no Brasil. 


\section{DADOS}

Em todo caso, que modelo seria melhor escolher? Evidentemente, o melhor é o Modelo 2, porque os coeficientes das variáveis independentes são mais altos, seus graus de significância também são mais elevados e seu $\mathrm{R}^{2}$ ajustado é mais alto (embora apenas ligeiramente superior ao do Modelo 1). Mantendo Decurso constante nesse modelo, o aumento de uma unidade em Gabinete está aproximadamente associado com o aumento de uma unidade na taxa de coalescência do Ministério. Assim, por exemplo, se um presidente demite um gabinete que obtinha o valor de 0,4 em Gabinete e o substitui por outro que alcança o valor de 0,6, provavelmente se observará um aumento de 0,19 na coalescência do Gabinete. Mantendo Gabinete constante, o coeficiente obtido em Decurso indica que se uma votação nominal se realiza quando ainda faltam mil dias (cerca de 3 anos) para terminar o mandato presidencial, a disciplina legislativa provavelmente aumentará de 0,08 quando comparada com uma votação que se realiza no fim do mandato.

O significado desses resultados é claro: gabinetes em que a taxa de coalescência é alta maximizam a disciplina legislativa dos partidos governistas; à medida que o mandato presidencial se aproxima do seu término, a coalescência diminui.

\section{O APOIO DE PARTIDOS ESPECÍFICOS AO EXECUTIVO}

Esta seção descreve os testes relativos ao apoio dado por partidos específicos ao presidente da República. Vejamos rapidamente os perfis dos partidos mais relevantes.

No centro da escala esquerda-direita, o partido mais importante é o PMDB. Apesar de um acentuado declínio desde 1988, foi este o maior partido brasileiro no período 1985 a 1996, tendo ocupado a Presidência da República durante o governo Sarney (1985-1990). A Tabela 2 indica que o PMDB esteve presente em onze dos quatorze ministérios formados no período 1985-1998.

À direita, o Partido da Frente Liberal PFL aparece como o partido de maior relevância. Este tornou-se o segundo maior partido do país em 1986 e desde 1997 é o maior, tendo participado de todos os ministérios formados a partir de 1985.

Finalmente, o Partido da Social Democracia Brasileira PSDB, fundado em 1988 durante a Assembléia Nacional Constituinte como uma dissidência do PMDB, é um partido de centro-esquerda cuja importância vem crescendo desde a eleição, em 1994, de um de seus líderes, Fernando Henrique Cardoso, para a Presidência da República, e sua posterior reeleição em 1998. Converteu-se no terceiro maior partido parlamentar do país em 1995, e desde as eleições de 1998 ocupa a segunda posição entre os principais partidos nacionais. O PSDB foi recrutado para o Ministério pelo presidente Collor em 1992; desde então sempre ocupou postos ministeriais de grande relevo.

Minha hipótese é a de que os partidos cooperam com os presidentes quando percebem vantagens em fazê-lo. Entre estas vantagens podem estar a promoção de carreiras políticas, o acesso a recursos clientelísticos, ou a implementação de projetos de sua preferência. Uma das formas de um político assegurar-se desses benefícios é ocupar postos ministeriais. Para se manterem nos cargos, os ministros têm de trabalhar para assegurar o apoio do seu partido ao presidente da República. E mais, os parlamentares têm de partilhar os recursos clientelísticos obtidos caso seu líder mantenha o cargo ministerial. Portanto, minha hipótese é a seguinte:

H4. Quanto melhor é a representação de um partido no Gabinete, mais forte é o apoio ao presidente nas votações nominais.

Para verificar esta hipótese, analiso o apoio de partidos específicos ao presidente da República como sendo uma função da extensão em que são contemplados com recompensas ministeriais. A variável dependente é operacionalizada como o percentual da bancada parlamentar de um dado partido que vota de acordo com a orientação do líder do governo em votações nominais (denomino essa variável de Apoio).

Apoio $_{i}=\%$ da bancada de um partido na Câmara dos Deputados que vota com o líder do governo em uma votação nominal

Note-se que a variável Apoio, assim como Disciplina, inclui todas as formas de comportamento não cooperativo com o presidente (representado pelo seu líder no Plenário). Isto é, abstenções e ausências estão incluídas no denominador.

Meço a taxa de recompensa ministerial, a principal variável independente, pelo quociente entre o percentual de postos ministeriais controlados pelo partido e o percentual de cadeiras que detém dentro do total de deputados que pertencem aos partidos representados no Gabinete (denomino esse índice de Recompensa). A fórmula é a seguinte:

Recompensa $_{i}=M_{i} / S_{i}\left(M_{i}\right.$ e $S_{i}$ foram definidos na seção II ) 


\section{DADOS}

Portanto, se um partido recebe 0,35 dos postos ministeriais e controla 0,60 das cadeiras do contingente parlamentar dos partidos presentes no Gabinete, seu valor em Recompensa será de 0,35/0,60 =0,58. Se um partido não recebe nenhuma pasta ministerial, seu escore em Recompensa é obviamente zero. Espero que Recompensa venha a ter um sinal positivo. A Tabela 6 apresenta os valores de Recompensa para o PMDB, PFL e PSDB para todos os ministérios nomeados entre 1985 e 1998.

Tabela 6

Taxa de Recompensa Ministerial do PMDB, PFL e PSDB (1985-1998)

\begin{tabular}{|c|c|c|c|}
\hline \multirow{2}{*}{$\begin{array}{l}\text { Presidente e } \\
\text { Gabinete }\end{array}$} & \multicolumn{3}{|c|}{ Partidos } \\
\hline & PMDB & PFL & PSDB \\
\hline Sarney I & 1,17 & 0,54 & 0,00 \\
\hline Sarney II & 0,71 & 0,51 & 0,00 \\
\hline Sarney III & 0,44 & 0,35 & 0,00 \\
\hline Collor I & 0,19 & 0,53 & 0,00 \\
\hline Collor II & 0,00 & 0,32 & 0,00 \\
\hline Collor III & 0,00 & 0,30 & 0,00 \\
\hline Collor IV & 0,00 & 0,45 & 0,50 \\
\hline Itamar I & 0,57 & 0,64 & 1,41 \\
\hline Itamar II & 0,58 & 0,51 & 1,31 \\
\hline Itamar III & 0,46 & 0,40 & 0,78 \\
\hline Itamar IV & 0,38 & 0,44 & 0,86 \\
\hline Itamar V & 0,13 & 0,27 & 0,25 \\
\hline $\mathrm{FHC} \mathrm{I}$ & 0,27 & 0,49 & 1,40 \\
\hline FHC II & 0,13 & 0,56 & 1,10 \\
\hline
\end{tabular}

Fonte: Cpdoc (s/d) e dados fornecidos por Antônio Octávio Cintra e José L. M. Dias.

Outras fontes: Sobre Sarney: Keesing's Contemporary Archives, vol. 31, o 6, 1985, pp. 33642-33650; Veja, 12/2/1986, pp. 16-21; Veja, 11/1/1989, pp. 34-36; sobre Collor: Veja, 14/3/1990, pp. 26-31; Veja, 15/4/1992, pp. 18-26; sobre Itamar: Veja, 7/10/1992, pp. 34-49; Jornal do Brasil, 20/8/1993, p. 2; Jornal do Brasil, 21/8/1993, p. 4; Jornal do Brasil, 29/8/1993, p. 12; sobre FHC: IstoÉ, 4/1/1995, pp. 21-22.

Complementarmente, a variável Decurso, que mede o impacto do ciclo eleitoral na disciplina legislativa, também será incluída nos testes para partidos específicos, assim como nos testes com medidas agregadas de disciplina legislativa e coalescência do Gabinete. Mais uma vez, espero que Decurso tenha um sinal positivo. Ou seja,

H5. À medida que o mandato presidencial decorre, diminui o apoio do partido ao presidente nas votações nominais.

Por fim, a distância ideológica entre partidos específicos e o presidente é evidentemente um fator de influência na disposição dos primeiros para apoiar o segundo. A hipótese, nesse caso, é semelhante à H3. H6. Quanto maior a distância ideológica entre um partido e o presidente, mais fraco é o apoio do partido ao presidente nas votações nominais.

Para operacionalizar a distância ideológica entre um partido e o chefe do Executivo, suponho primeiramente que a posição ideológica do presidente é a mesma do seu partido. Até que ponto isso é 


\section{DADOS}

plausível? É claro que no mundo real da política os presidentes diferem ideologicamente dos seus partidos. A realidade do poder geralmente torna os presidentes mais conservadores do que seu partido quando este tem tendências de esquerda. É o que acontece com o presidente Fernando Henrique e seu partido, o PSDB. Mas o inverso também é verdadeiro: quando o partido do presidente tem inclinações direitistas, o chefe do Executivo tende a parecer mais progressista. Um bom exemplo é o presidente Juscelino Kubitschek, cujas posições políticas pareciam estar à esquerda do conservador Partido Social Democrático PSD. De qualquer modo, pode-se supor que a legenda partidária de um presidente é uma pista confiável sobre a inclinação de suas preferências em um grande número de questões. Determinada a posição ideológica do presidente, suponho que a distância entre ele e o partido é igual ao valor absoluto da distância entre a posição de cada um na escala esquerda-direita, conforme é definido pela seguinte fórmula:

Distância $=\left|P_{\text {pres }}-P_{i}\right|$

onde,

$P_{\text {pres }}=$ a posição ideológica do partido do presidente na escala esquerda-direita;

$\mathrm{P}_{\mathrm{i}}=$ a posição ideológica do partido i na escala esquerda-direita.

Por exemplo, a distância ideológica entre um presidente de centro-direita e um partido de centroesquerda é de 1,0. O único presidente brasileiro que cria uma dificuldade operacional a essa variável é Itamar Franco. Quando de sua posse em outubro de 1992, Itamar não estava filiado a nenhum partido. Mas durante a maior parte de sua carreira política, ele esteve ligado ao PMDB, tendo se desligado deste partido pouco antes de ser incluído na chapa de Fernando Collor, em 1989. No exercício da Presidência da República, Itamar assumiu posições mais moderadas, centristas, semelhantes às do seu antigo partido. Portanto, equiparar as posições de Itamar e do PMDB não é uma total violação da realidade.

Considerando tudo isso, a equação que representa os efeitos aditivos das variáveis independentes que se referem aos cargos, votos e ideologia de um partido relativamente ao seu apoio ao presidente nas votações nominais toma a seguinte forma:

Apoio $_{i}=$ ß $4+$ ß 5 Recompensa + ß 6 Decurso + ß 7 Distância + (eq. 2)

Resultados

A Tabela 7 apresenta os resultados da regressão para partidos específicos. As três variáveis independentes foram significantes para o PMDB, e tiveram o sinal certo. Mantendo outros fatores constantes, se a taxa de recompensa do PMDB pula de 0,5 (o que quer dizer que apenas metade do partido está corretamente representada no Gabinete) para 1,0 (uma representação perfeitamente proporcional), o apoio do partido ao presidente deve crescer de 0,22; se uma votação nominal for realizada quando faltam três anos para terminar o mandato presidencial, o apoio desse partido deve aumentar de 0,1 em comparação com uma votação que se realize no fim do governo; e se um presidente de centro for substituído por outro de direita, o apoio do PMDB deve cair de 0,1.

Tabela 7

Os Determinantes do Apoio do PMDB, PFL e PSDB ao Presidente (1989-1998) ${ }^{1}$

\begin{tabular}{|l|l|l|l|}
\hline \multicolumn{2}{|l|}{ Variável Dependente: Apoio ao Presidente do PMDB, PFL e PSDB } \\
\hline & Partidos \\
\hline $\begin{array}{l}\text { Variáveis } \\
\text { Independentes }\end{array}$ & PMDB & PFL & PSDB \\
\hline Constante & $\begin{array}{l}0,355^{* * *} \\
(0,074)\end{array}$ & $\begin{array}{l}0,224 * * * \\
(0,079)\end{array}$ & $\begin{array}{l}0,583 * * * \\
(0,065)\end{array}$ \\
\hline Recompensa & $\begin{array}{l}0,447 * * * \\
(0,049)\end{array}$ & $\begin{array}{l}0,664 * * * \\
(0,160)\end{array}$ & $\begin{array}{l}0,174 * * * \\
(0,055)\end{array}$ \\
\hline Decurso & $\begin{array}{l}0,0001 * * * \\
(0,00003)\end{array}$ & $\begin{array}{l}0,00007 * * \\
(0,00002)\end{array}$ & $\begin{array}{l}-0,00003 \\
(0,00003)\end{array}$ \\
\hline Distância & $\begin{array}{l}0,097 * \\
(0,051)\end{array}$ & $\begin{array}{l}0,076 * * * \\
(0,024)\end{array}$ & $\begin{array}{l}-0,148 * * * \\
(0,051)\end{array}$ \\
\hline R ajustado & 0,139 & 0,158 & 0,434 \\
\hline No de Observações & 324 & 324 & 324 \\
\hline
\end{tabular}

${ }^{1}$ Os erros-padrão estão indicados entre parênteses.

$* * * \mathrm{p}>0,01 ; * * \mathrm{p}>0,05 ; * \mathrm{p}>0,1$. 


\section{DADOS}

No que diz respeito ao PFL, tanto Recompensa quanto Decurso e Distância tiveram efeitos significantes em Apoio, embora em diferentes níveis $(0,01,0,05$ e 0,1 , respectivamente). Mas Distância veio com o sinal errado, o que confirmou a hipótese nula. Tudo o mais mantido constante, se a taxa de recompensa para o PFL passa de 0,5 para 1,0, o apoio do partido ao presidente deve aumentar de 0,33; uma votação nominal realizada três anos antes do fim do mandato presidencial deve coincidir com o aumento do apoio do partido ao presidente de 0,07 em comparação com uma votação realizada no final do seu mandato.

Por último, no caso do PSDB, apenas Recompensa e Distância foram significantes (ambos no nível de 0,01 ) e vieram com o sinal certo. Tudo o mais mantido constante, se a recompensa do PSDB passar de 0,5 para 1,0, o apoio ao presidente deve aumentar de 0,09, e se um presidente de centro for substituído por outro de direita, o apoio do PSDB deverá diminuir de $0,15^{\underline{12}}$.

Por que Distância veio com o sinal errado para o PFL? Estudiosos dos partidos conservadores no Brasil (Hagopian, 1996; Power, 2000) afirmam que o PFL é um partido essencialmente clientelista. Partidos desse tipo se interessam basicamente pelas vantagens do poder. Não admira que o PFL tenha participado de todos os gabinetes governamentais desde 1985. Portanto, o sinal positivo em Distância que o PFL obteve na equação de regressão e sua significância estatística podem ser considerados espúrios.

Finalmente, por que Decurso não teve um impacto significativo no apoio do PSDB ao presidente? O PSDB é sem dúvida o partido de compromissos ideológicos mais fortes entre as três maiores organizações político-partidárias do Brasil. É muito menos clientelista do que o PFL e menos heterogêneo do que o PMDB. Pode-se dizer, portanto, que, uma vez que o PSDB se decida a apoiar um governo (não participou do governo Sarney nem dos três primeiros ministérios de Collor), seu padrão de relacionamento com o chefe do Executivo permanecerá estável até o fim do mandato presidencial. Desse modo, uma variável que mede o decurso desse mandato não terá um impacto significante no apoio do partido ao presidente.

Em suma, o apoio parlamentar dos dois maiores partidos brasileiros PMDB e PFL ao chefe do Executivo é determinado principalmente pela relação entre a recompensa ministerial recebida por estes partidos e o decurso do mandato presidencial. No caso de um partido mais ideológico, como o PSDB, a distância ideológica entre o presidente e o partido também tem um papel importante, e o decurso do mandato presidencial não produz efeitos significantes no apoio do partido ao Executivo.

\section{CONCLUSÃO}

Retomemos agora a pergunta feita na Introdução deste artigo: será que gabinetes presidenciais podem funcionar como os arranjos de coalizão dos regimes parlamentaristas? A análise do caso brasileiro aqui realizada nos permite tirar as conclusões abaixo mencionadas.

Em primeiro lugar, não se deve pressupor que um Gabinete presidencial integrado por políticos de dois ou mais partidos constitua um governo de coalizão. Somente os gabinetes que apresentam uma alta correspondência entre o percentual de postos ministeriais e os pesos dos partidos no Congresso (relativamente ao contingente parlamentar dos partidos que integram o Ministério) podem ser considerados como tal em uma interpretação estrita do termo coalizão. Em segundo lugar, uma alocação judiciosa dos postos ministeriais entre os partidos, baseada na regra de proporcionalidade, especialmente no início do mandato presidencial, aproxima o comportamento legislativo dos partidos que integram o Gabinete multipartidário ao dos partidos em um sistema parlamentarista. Isto é, um comportamento altamente disciplinado da coalizão nas votações legislativas deve ser observado nos gabinetes presidenciais que ostentam esses atributos. Em terceiro lugar, partidos mais ideológicos demonstram um comportamento legislativo mais consistente ao longo do tempo.

Até que ponto esses resultados são generalizáveis? É bem provável que eles se sustentem em todos os sistemas presidencialistas nos quais os partidos não são nem muito disciplinados nem muito faccionalizados e em que a patronagem do Executivo na forma de cargos ministeriais é uma moeda política importante. Assim, existindo dados, as equações 1 e 2 podem muito bem ser aplicadas a países como a Bolívia, o Chile, a Colômbia, o Equador, o Peru, antes de Fujimori, e o Uruguai. Provavelmente não se aplicam à Venezuela do período pré-Chávez, devido à perfeita disciplina dos partidos venezuelanos, nem aos Estados Unidos, por causa da pequena importância dos cargos ministeriais para os partidos políticos americanos.

De que maneira a disciplina legislativa ajuda os presidentes? É importante assinalar, antes de tudo, que o fato de um presidente brasileiro contar com uma coalizão disciplinada, em virtude da distribuição judiciosa de postos ministeriais entre os partidos, não significa que ele tenha uma maioria estável no Congresso. A Tabela 2 mostra que quase todos os ministérios brasileiros tiveram o controle nominal de uma maioria na Câmara dos Deputados, mas os presidentes estão sempre lutando para reunir maiorias 


\section{DADOS}

legislativas. No entanto, se o contingente parlamentar do presidente se comporta de modo disciplinado, isso certamente o ajuda a negociar uma maioria com os partidos de oposição porque lhe dá condições mais sólidas de barganha. É por isso que os presidentes que nomeiam gabinetes mais coalescentes tendem a ser mais estáveis no Brasil.

O exemplo do presidente Fernando Collor de Mello (1990-1992) é bem ilustrativo disso. Quando assumiu o poder em março de 1990, o partido de Collor na Câmara dos Deputados, o Partido da Reconstrução Nacional PRN, controlava apenas $5,1 \%$ das cadeiras. A situação parlamentar do presidente era, portanto, bastante difícil em termos de apoio partidário, e complicou-se ainda mais quando aumentou a percepção de que ele estava excessivamente à direita do espectro político. Para reunir uma maioria parlamentar estável, o presidente teria de fazer um número enorme de concessões aos principais partidos. Entretanto, o artigo 62 da Constituição conferia-Ihe o poder de editar decretos com força de lei (as medidas provisórias). Logo no dia de sua posse, Collor deixou bem clara sua estratégia política: decidiu enfrentar a crise hiperinflacionária em que o Brasil estava mergulhado desde 1987 exclusivamente por meio de medidas provisórias. Assinou nada menos que 36 decretos durante os primeiros quinze dias de seu governo (e 163 durante o ano de 1990) $\frac{13}{3}$, e nomeou um Ministério composto majoritariamente de amigos e tecnocratas.

Collor governou por medidas provisórias durante todo o seu primeiro ano de mandato e o começo do segundo, apesar do crescente descontentamento com a maneira como ele se relacionava com 0 Congresso e com o desempenho geral de seu governo. A insatisfação era tão grande que em abril de 1991 o Congresso quase aprovou um projeto (conhecido como projeto Nelson J obim) que regulamentava e limitava a edição de medidas provisórias pelo Executivo. Nas palavras de Power:

"Embora Jobim e seus aliados não tivessem conseguido reformular o artigo 62 da Constituição, seu esforço pode ter repercutido favoravelmente em Collor e seus conselheiros. Enquanto o projeto Jobim estava sendo discutido no Congresso, em fevereiro, março e abril, Collor não editou uma única MP [...] A julgar pelo seu primeiro ano de governo, seu comedimento era espantoso. É difícil evitar a conclusão de que o presidente imaginava que seu bom comportamento poderia salvá-lo de uma restrição de seu poder de emitir decretos por uma decisão do Congresso" (1998:211).

Em certo sentido, a votação do projeto Jobim marcou uma mudança profunda no governo de Collor. Em 1991, ele assinou apenas oito medidas provisórias em comparação com as 163 do ano anterior, o que indica um declínio contínuo de seu apoio parlamentar. Durante todo o ano de 1991, porém, Collor se recusou a negociar um acordo com os partidos de oposição para melhorar as relações entre Executivo e Legislativo, e insistiu em manter o Congresso a distância. Em conseqüência desse impasse, pouco foi feito no ano de 1991 para atacar o principal problema brasileiro a hiperinflação. Em dezembro de 1990, a taxa mensal de inflação era de 16,0\%; em dezembro de 1991, já chegava a $23,3 \% \underline{14}$. Em janeiro de 1992, Collor reformou seu Ministério com o objetivo de angariar um apoio mais sólido por parte dos partidos conservadores $\frac{15}{}$. Não é difícil entender as razões do seu notório fracasso: o Gabinete tinha uma taxa de coalescência de apenas 0,30. No primeiro trimestre de 1992, já se percebiam sinais inquietantes de que o governo Collor estava afundando. A inflação mensal passava da casa dos $20 \%$. A popularidade do presidente desabava: em março de 1992, uma pesquisa nacional mostrou que apenas $15,4 \%$ dos entrevistados consideravam o governo Collor bom ou muito bom, em comparação com 35,3\% em agosto de $1960,23,3 \%$ em março de 1991 e $20,4 \%$ em agosto de $1991^{16}$. Além disso, denúncias de corrupção contra ministros e assessores do presidente apareciam cada vez mais freqüentemente nas manchetes de jornais e revistas. Era óbvio que Collor precisava, antes de qualquer coisa, fortalecer seu apoio no Congresso para conseguir inaugurar uma nova fase, mais afortunada, de seu mandato. Em fins de março de 1992, Collor demitiu todo o Ministério e pela primeira vez em seu período presidencial, admitiu publicamente que estava iniciando negociações com os partidos políticos para formar uma maioria legislativa ${ }^{17}$. Acabou compondo o Ministério mais coalescente de todo seu governo (Gabinete $=0,46$ ), com o que, por fim, tentava atrair apoio parlamentar mediante uma alocação mais criteriosa dos postos ministeriais entre os partidos políticos. Se Collor não tivesse sofrido o impeachment, pode supor-se que seu novo Gabinete se teria saído melhor em termos de apoio legislativo do que os anteriores. Evidentemente, sempre se deve encarar esse tipo de especulação a posteriori com algumas reservas. Resta saber por que razão ele levou tanto tempo para mudar seu Ministério a fim de obter apoio parlamentar. Uma explicação plausível é que talvez ele estivesse convencido de que com um verdadeiro Gabinete de coalizão a autonomia decisória de que desfrutara durante seu primeiro ano de governo seria muito reduzida. Seja como for, o exemplo de Collor demonstra a existência de uma clara, embora frouxa, conexão entre a coalescência do Gabinete e o apoio legislativo dos partidos que ocupam ministérios. É possível multiplicar inúmeras vezes esse tipo de exemplo para outros presidentes brasileiros e latinoamericanos, como revela a análise quantitativa realizada neste artigo.

(Recebido para publicação em abril de 2000) 


\section{DADOS}

\section{NOTAS:}

* Este artigo foi financiado pela Fundação de Amparo à Pesquisa do Estado do Rio de Janeiro FAPERJ com a bolsa E-26/150.194/98-Bolsa. Agradeço a Gary W. Cox, Arend Lijphart, Fernando Limongi, Scott Morgenstern e Benito Nacif por seus valiosos comentários às versões preliminares do texto. $A$ responsabilidade por seu conteúdo cabe exclusivamente ao autor. Agradeço também a Argelina C. Figueiredo, Fernando Limongi e Jairo Nicolau pela cessão de seus dados a respeito das votações nominais nas legislaturas brasileiras do período 1989-1998. Este artigo será publicado como um dos capítulos do livro Legislative Politics in Latin America, organizado por Scott Morgenstern e Benito Nacif e publicado pela Cambridge University Press. [Tradução do original em inglês "Presidential Cabinets, Electoral Cycles, and Coalition Discipline in Brazil" é de Vera Pereira.]

1. Por Gabinete presidencial entende-se o conjunto de assessores do presidente com status ministerial. Os termos Gabinete e Ministério serão utilizados indiferentemente ao longo do texto.

2. Cabe observar que Figueiredo e Limongi afirmam que os partidos brasileiros são bastante disciplinados e se comportam de maneira previsível.

3. Para uma análise da aplicação dessa medida aos ministérios de dez países latino-americanos, ver Amorim Neto (1998, cap. 3).

4. Emprego o conceito de equilíbrio no sentido de um equilíbrio de Nash, isto é, uma situação em que nenhum ator tem incentivos para agir unilateralmente.

5. Aqui focalizo apenas os problemas de fragmentação parlamentar e dos poderes presidenciais, deixando de fora a questão do federalismo. Os leitores interessados nesse último tema devem consultar os trabalhos de Abrúcio (1998), Dias (1997), Mainwaring (1997) e Samuels e Abrúcio (1997).

6. Outros resumos da Constituição de 1988 podem ser encontrados em Carey, Amorim Neto e Shugart (1997) e Mainwaring (1997).

7. Cabe fazer alguns comentários adicionais sobre as impressionantes taxas de migração partidária no Brasil. A Tabela 3 mostra que a fragmentação é variável em uma mesma legislatura. A migração partidária é a principal causa disso porque altera a distribuição das cadeiras entre os partidos durante uma mesma legislatura. Ao mudar de partidos ou os deputados vão para legendas antigas ou criam novas. De acordo com Nicolau (1996:65), 64,6\% dos parlamentares eleitos em 1994 mudaram de partido pelo menos uma vez desde 1980. Alguns deputados chegam a trocar de filiação partidária duas vezes na mesma legislatura. A migração partidária atingiu seu auge no final da década de 80 . 0 número efetivo de partidos com representação parlamentar que emergiu da eleição de 1986 foi de 2,8. No entanto, devido à migração, esse número pulou para 4,1, em 1988, para 5,5 em 1989, e 7,1 em 1990, 0 último ano dessa legislatura.

8. Nos países em que a disciplina partidária é rígida, como na Venezuela no período 1959-1993, a análise dos votos nominais não tem sentido algum (Coppedge, 1994).

9. De acordo com Carey, como algumas votações exigem maiorias extraordinárias, o índice de relevância deveria ser devidamente ajustado. Por exemplo, se há exigência de uma maioria especial de 0,67 do total dos deputados, esse valor deveria ser adotado em substituição ao de 0,5. Existem no Brasil três tipos de maiorias: simples (para projetos de lei orgânica), absoluta em relação à totalidade dos membros da legislatura (para projetos de lei complementar, que regulamentam artigos constitucionais) e maioria de 0,6 da totalidade dos parlamentares (para emendas constitucionais). Como não disponho de informações sobre o tipo de maioria exigido em cada votação nominal, optei por uma solução de meiotermo, 0,5, o que quer dizer que se exige uma maioria absoluta.

10. Note-se que a diversidade ideológica é uma característica de governo de grande importância para a sobrevivência dos gabinetes nas democracias parlamentaristas (Warwick, 1994:49-74). Tsebelis (1995) afirma que as mesmas variáveis que explicam a falência das democracias presidencialistas são responsáveis pela dissolução dos gabinetes nas democracias parlamentaristas o número de partidos com poder de veto e a heterogeneidade das preferências. Entretanto, com o suposto da estabilidade democrática, a disciplina da coalizão como uma função da diversidade ideológica do gabinete é o equivalente funcional no presidencialismo à sobrevivência do gabinete no parlamentarismo.

11. Segundo Coppedge (1997) e Mainwaring (1999), a posição ideológica dos doze partidos que participaram de ministérios pelo menos uma vez desde 1985 é a seguinte: na esquerda, Partido dos Trabalhadores PT, Partido Socialista Brasileiro PSB e Partido Popular Socialista PPS; na centroesquerda, Partido da Social Democracia Brasileira PSDB e Partido Democrático Trabalhista PDT; no centro, PMDB; na centro-direita, Partido Trabalhista Brasileiro PTB; na direita, PFL, PDS, Partido Progressista Brasileiro PPB, Partido Liberal PL e Partido da Reconstrução Nacional PRN.

12. Não foram encontrados problemas de autocorrelação em nenhuma das regressões.

13. Dados fornecidos por Jorge Vianna Monteiro.

14. Dados fornecidos pelo Departamento de Economia da Pontifícia Universidade Católica do Rio de Janeiro PUC-RJ.

15. Ver Veja, "Faxina em Casa: Collor demite Alceni e Chiarelli, cria um Ministério para Bornhauser e convoca o PFL, para dar um novo desenho político ao governo", 29/1/1992. 


\section{DADOS}

16. Esses números foram fornecidos pelo Centro de Estudos de Opinião Pública Cesop, da Universidade de Campinas.

17. Ver, por exemplo, O Globo, "Collor dissolve o Governo irritado com denúncias diárias de corrupção, presidente inicia reforma ampla do ministério", 31/3/1992; Folha de S. Paulo, "Governo tenta compor base partidária", 31/3/1992.

\section{REFERÊNCI AS BI BLI OGRÁFI CAS}

ABRANCHES, Sérgio H. H. de. (1988), "Presidencialismo de Coalizão: O Dilema Institucional Brasileiro". Dados, vol. 31, no 1, pp. 5-38.

ABRÚCIO, Fernando Luiz. (1998), Os Barões da Federação: Os Governadores e a Redemocratização Brasileira. São Paulo, Hucitec.

ALTMAN, David. (1998), The Politics of Coalition Formation and Survival in Multiparty Presidential Democracies: The Case of Uruguay (1982-1997). Trabalho apresentado na 94a Reunião Anual da American Political Science Association APSA. Boston, 3-6 de setembro.

AMORIM NETO, Octavio. (1994), "Formação de Gabinetes Ministeriais no Brasil: Coalizão versus Cooptação". Nova Economia, no 4, pp. 9-34.

(1995), Party Politics and Cabinet Formation in Brazil. Trabalho apresentado no 19o Encontro da Latin American Studies Association LASA. Washington, D.C., 28-30 de setembro.

(1998), Of Presidents, Parties, and Ministers: Cabinet Formation and Legislative Decision-Making under Separation of Powers. Tese de Doutorado, University of California, San Diego.

e COX, Gary W. (1997), "Electoral Institutions, Cleavage Structures, and the Number of Parties". American J ournal of Political Science, no 41, pp. 149-174.

AMORIM NETO, Octavio e SANTOS, Fabiano. (no prelo), "The Executive Connection: PresidentiallyDefined Factions and Party Discipline in Brazil". Party Politics, vol. 7.

BOND, J on R. e FLEISHER, Richard. (1990), The President in the Legislative Arena. Chicago, The University of Chicago Press.

BROWNE, Eric C. e FRANKLIN, Mark N. (1973), "Aspects of Coalition Payoffs in European Parliamentary Democracies". American Political Science Review, no 67, pp. 453-468.

BUDGE, Ian e KEMAN, Hans. (1990), Parties and Democracy: Coalition Formation and Government Functioning in Twenty States. New York, Oxford University Press.

CAREY, John M. (1999), "Party and Coalition Unity in Legislative Voting". Working Paper no 376 , Department of Political Science, Washington University at Saint Louis.

AMORIM NETO, Octavio e SHUGART, Mathew S. (1997), "Outlines of Constitutional Powers in Latin America", in S. Mainwaring e M. S. Shugart (eds.), Presidentialism and Democracy in Latin America. Cambridge, Cambridge University Press.

COPPEDGE, Michael. (1994), "Venezuela: Democratic Despite Presidentialism", in J. J. Linz e A. Valenzuela (eds.), The Failure of Presidential Democracy: The Case of Latin America (vol. 2). Baltimore, The Johns Hopkins University Press.

(1997), "A Classification of Latin American Political Parties". Working Paper no 244, Kellog Institute. (1998), "The Dynamic Diversity of Latin American Party Systems". Party Politics, no 4, pp. 547-568. CPDOC. (s/d), Ministros de Estado da República. Rio de Janeiro, Fundação Getulio Vargas Editora.

DEHEZA, Grace Ivana. (1997), Gobiernos de Coalición en el Sistema Presidencial: América del Sur. Tese de Doutorado, European University Institute, Firenze.

. (1998), "Gobiernos de Coalición en el Sistema Presidencial: América del Sur", in D. Nohlen e M. Fernández B. (eds.), El Presidencialismo Renovado: Instituciones y Cambio Político en América Latina. Caracas, Nueva Sociedad.

DIAS, José Luciano de Mattos. (1997), Federalismo, Governos Estaduais e Políticas Públicas: Uma Análise das Instituições Federais no Brasil. Tese de Doutorado, IUPERJ, Rio de Janeiro.

FIGUEIREDO, Argelina Cheibub e LIMONGI, Fernando. (1995), "Partidos Políticos na Câmara dos Deputados: 1989-1994". Dados, vol. 38, no 3, pp. 497-524.

(1997), "O Congresso e as Medidas Provisórias: Abdicação ou Delegação". Novos Estudos Cebrap, no ${ }^{-}$47, pp. 127-154.

HAGOPIAN, Frances. (1996), Traditional Politics and Regime Change in Brazil. New York, Cambridge University Press.

JONES, Mark. P. (1995), Electoral Laws and the Survival of Presidential Democracies. Notre Dame, University of Notre Dame Press.

KINZO, Maria D’Alva Gil. (1993), Radiografia do Quadro Partidário Brasileiro. São Paulo, Konrad Adenauer-Stiftung.

LAAKSO, Marku e TAAGEPERA, Rein. (1979), "Effective Number of Parties: A Measure with Application to West Europe". Comparative Political Studies, no 12, pp. 3-27.

LAMOUNIER, Bolívar. (1994), "Brazil at an Impasse". J ournal of Democracy, no 5, pp. 72-87.

LAVER, Michael e SCHOFIELD, Norman. (1990), Multiparty Government: The Politics of Coalition in Europe. New York, Oxford University Press. 


\section{DADOS}

LIJPHART, Arend. (1992), "Introduction", in A. Lijphart (ed.), Presidential versus Parliamentary Government. New York, Oxford University Press.

LIMA JUNIOR, Olavo Brasil de. (1993), Democracia e Instituições Políticas no Brasil dos Anos 80 . São Paulo, Edições Loyola.

LIMONGI, Fernando e FIGUEI REDO, Argelina Cheibub. (1998), "Bases Institucionais do Presidencialismo de Coalizão". Lua Nova, no 44, pp. 81-106.

LINZ, Juan J. (1994), "Presidential versus Parliamentary Democracy: Does It Make a Difference?", in J. J. Linz e A. Valenzuela (eds.), The Failure of Presidential Democracy: The Case of Latin America (vol. 2). Baltimore, The Johns Hopkins University Press.

MAINWARING, Scott. (1993), "Presidentialism, Multiparty Systems and Democracy: The Difficult Equation". Comparative Political Studies, no 26, pp. 198-228.

(1997), "Multipartism, Robust Federalism, and Presidentialism in Brazil", in S. Mainwaring e M. S. Shüuart (eds.), Presidentialism and Democracy in Latin America. Cambridge, Cambridge University Press. (1999), Rethinking Party Systems in the Third Wave of Democratization: The Case of Brazil. Stanford, Stanford University Press.

e PÉREZ LIÑÁN, Aníbal. (1998), "Party Discipline in the Brazilian Constitutional Congress". Legislative

Stüdies Quarterly, no 22, pp. 453-483.

MAINWARING, Scott e SHUGART, Matthew S. (1997), "Conclusion: Presidentialism and the Party System", in S. Mainwaring e M. S. Shugart (eds.), Presidentialism and Democracy in Latin America. Cambridge, Cambridge University Press.

MENEGUELLO, Rachel. (1998), Partidos e Governos no Brasil Contemporâneo (1985-1997). São Paulo, Paz e Terra.

NICOLAU, Jairo Marconi. (1996), Multipartidarismo e Democracia: Um Estudo sobre o Sistema Partidário Brasileiro (1985-94). Rio de J aneiro, Fundação Getulio Vargas Editora.

PESSANHA, Charles. (1997), Relações entre os Poderes Executivo e Legislativo no Brasil: $1946-1994$. Tese de Doutorado, USP, São Paulo.

POWER, Timothy J. (1998), "The Pen is Mightier than the Congress: Presidential Decree Power in Brazil", in J. M. Carey e M. S. Shugart (eds.), Executive Decree Authority. New York, Cambridge University Press.

(2000), The Political Right in Postauthoritarian Brazil: Elites, Institutions, and Democratization. College Park, Penn State University Press.

RIKER, William H. (1959), "A Method for Determining the Significance of Roll Calls in Voting Bodies", in J. C. Wahlke e H. Eulau (eds.), Legislative Behavior: A Reader in Theory and Research. Glencol, The Free Press.

ROSE, Richard. (1984), "Electoral Systems: A Question of Degree or of Principle?", in A. Lijphart e B. Grofman (eds.), Choosing and Electoral System: Issues and Alternatives. New York, Praeger.

SAMUELS, David J. e ABRÚCIO, Fernando Luiz. (1997), The New Politics of the Governors: Subnational Politics and the Brazilian Transition to Democracy. Trabalho apresentado na Reunião da International Political Science Association IPSA, Seul.

SANTOS, Fabiano. (1997), "Patronagem e Poder de Agenda na Política Brasileira". Dados, vol. 40, no 3, pp. 465-491.

SARTORI, Giovanni. (1997), Comparative Constitutional Engineering: An Inquiry into Structures, Incentives and Outcomes. New York, New York University Press.

SCHMITT, Rogério. (1999), Coligações Eleitorais e Sistema Partidário no Brasil. Tese de Doutorado, IUPERJ, Rio de Janeiro.

SCHOFIELD, Norman e LAVER, Michael. (1985), "Bargaining Theory and Portfolio Payoffs in European Coalition Governments 1945-83". British J ournal of Political Science, no 15, pp. 143-164.

STROM, Kaare. (1990), "A Behavioral Theory of Competitive Political Parties". American Journal of Political Science, no 34, pp. 565-598.

THIBAUT, Bernhard. (1996), Präsidentialismus und Demokratie in Lateinamerika: Argentinien, Brasilien, Chile und Uruguay im Historischen Vergleich. Oplade, Leske + Budrich.

(1998), "El Gobierno de la Democracia Presidencial: Argentina, Brasil, Chile y Uruguay en una Perspectiva Comparada", in D. Nohlen e M. Fernández B. (eds.), El Presidencialismo Renovado: Instituciones y Cambio Político en América Latina. Caracas, Nueva Sociedad.

TSEBELIS, George. (1995), "Decision Making in Political Systems: Veto Players in Presidentialism, Parliamentarism, Multicameralism, and Multipartyism". British Journal of Political Science, no 25, pp. 289325. (Tradução em português publicada pela Revista Brasileira de Ciências Sociais.)

WARWICK, Paul V. (1994), Government Survival in Parliamentary Democracies. New York, Cambridge University Press. 


\title{
DADOS
}

\author{
ABSTRACT \\ Presidential Cabinets, Electoral Cycles, and Coalition Discipline in Brazil
}

All presidential cabinets formed in Brazil between 1985 and 1998 included politicians from more than one party and could, in principle, be defined as coalition cabinets. The article evaluates to what extent this is a valid statement as far as the legislative behavior of the cabinet parties is concerned. An indicator is proposed for measuring the rate of cabinet coalescence, based on the ratio between the percentage of ministerial posts held by each party represented in the cabinet and the percentage of legislative seats held by each of these parties. Regression analysis is used to ascertain what impact the rate of cabinet coalescence has on the legislative discipline of cabinet parties. In addition to this coalescence index, the study also tests the effect of electoral cycles and the ideological range of cabinets on legislative discipline. Results indicate that the legislative discipline of cabinet parties is only consistent with what would be expected of coalition governments in parliamentary regimes when the cabinet displays a relatively high rate of coalescence. Findings also show that the party support to president tends to decrease over the course of the president's term and that the greater the ideological distance between the president and a given party, the lower the support rate this party will display for the head of government.

Keywords: presidential cabinets; coalition governments; legislative discipline

\section{RÉSUMÉ}

\section{Gouvernement Présidentiels, Cycles Électoraux et Discipline de Coalition au Brésil}

Tous les gouvernements formés au Brésil entre 1985 et 1998 comprennent des politiciens d'au moins deux partis. Tous pourraient être définis comme étant de coalition. Cet article cherche à évaluer la véracité de cette affirmation sous l'angle du comportement législatif des partis qui composent chaque gouvernement. Pour cela, il propose un indicateur qui mesure le taux de coalescence des gouvernements sur la base du rapport entre le pourcentage de ministères occupés par chaque parti représenté et le pourcentage de sièges législatifs détenus par chacun de ces partis. Par le moyen de l'analyse de régression, on vérifie l'impact de ce taux de coalescence sur la discipline législative des partis qui intègrent le gouvernement. Outre ce taux de coalescence, on vérifie aussi l'effet des cycles électoraux et de l'ampleur idéologique des gouvernements sur la discipline législative. Selon les résultats, ce n'est que sous des gouvernements avec des taux élevés de coalescence que les partis au gouvernement présentent une discipline législative en accord avec celle qu'on attend d'un gouvernement de coalition. Les tests démontrent aussi que pendant la durée du mandat présidentiel se produit un affaiblissement de la discipline législative des partis représentés au gouvernement et que plus un parti est éloigné idéologiquement du Président, plus son d'appui à ce dernier est réduit.

Mots-clé: gouvernement présidentiels; gouvernements de coalition; discipline législative 